\title{
Pengaruh Cara Pengolahan terhadap Mutu Bakteriologis Ikan Tongkol (Euthynnus affinis) Pindang Siap Santap
}

\author{
The Influence of Various Method of Cooking on Bacteriological Quality of Ready-to-Eat \\ Salted Little Tuna Fish (Euthynnus affinis)
}

\author{
Ekawati Purwijantiningsih ${ }^{*}$ dan Exsyupransia Mursyanti
}

Fakultas Teknobiologi Universitas Atma Jaya Yogyakarta, Jl. Babarsari 44 Yogyakarta 55281

E-mail: purwija@mail.uajy.ac.id *Penulis untuk korespodensi

\begin{abstract}
The objective of this present research was to know the influence of various way of cooking on bacteriological quality of ready-to-eat salted little tuna fish (Euthynnus affinis). Previous study has shown that bacteriological quality of salted tuna fish from markets in Yogyakarta were not fulfill the requirements based on SNI 01-2717-1992. It was shown that the aerobic plate counts were high, i.e. $2.4 \times 10^{5}-5.27 \times 10^{7} \mathrm{CFU} / \mathrm{g}$. Coliform count ranged from $<2.5 \times 10^{1}->6.5 \times 10^{6} \mathrm{CFU} / \mathrm{g}$. From the 20 samples observed, only 1 sample did not contain $V$. parahaemolyticus and 4 samples were negative from Salmonella. Therefore, it needs to be studied whether the various way of cooking such as frying, frying with flour, frying with egg and frying with chili sauce were effective in removing any of the groups of bacteria examined from salted little tuna fish sample. The bacterial groups examined as indicator of quality were Staphylococcus aureus, Coliform, Salmonella and Vibrio parahaemolyticus. The aerobic plate counts were also taken. The result showed that the various way of cooking were effective in reducing the aerobic plate counts, $S$. aureus and Coliform. Frying with chili sauce was the best cooking procedure because it can reduced the highest number of aerobic plate counts, S. aureus and Coliform. Salmonella and V. parahaemolyticus were not detected in all cooking samples.
\end{abstract}

Key words: cooking and frying methods, salted little tuna, bacteriological quality

Diterima: 26 Oktober 2007, disetujui: 27 Desember 2007

\section{Pendahuluan}

Keamanan dan kesehatan adalah suatu hal yang penting bagi manusia apalagi berkaitan dengan masalah pangan. Makanan merupakan hal yang pokok tidak saja untuk menopang kehidupan melainkan juga untuk memperbaiki pertumbuhan, meningkatkan kecerdasan, yang pada akhirnya untuk memperoleh kesehatan fisik dan rohani. Menurut Priyono dan Raharjo (2003), berbagai faktor dapat menjadi penyebab terjadinya gangguan kesehatan melalui makanan. Secara umum faktor penyebab tersebut dapat digolongkan menjadi tiga faktor utama yakni bahan baku, pengolahan serta personil yang secara bersamaan mempunyai peranan penting sebagai penyebab terjadinya gangguan kesehatan karena makanan.

Produk perikanan merupakan produk unggulan dalam pemenuhan gizi masyarakat, oleh karena itu pemantauan keamanan pangan perikanan maupun bentuk olahannya harus secara kontinyu dilakukan. Ikan, selain sumber protein, juga diakui sebagai functional food yang mempunyai arti penting bagi kesehatan karena mengandung asam lemak tidak jenuh berantai panjang, vitamin serta makro dan mikro mineral (Heruwati, 2002).

Ikan merupakan produk yang mudah sekali mengalami pembusukan. Hal tersebut disebabkan karena kandungan air dan protein 
yang tinggi pada ikan, serta adanya proses autolisis yakni proses penguraian jaringan yang berjalan dengan sendirinya setelah ikan mati. Proses pembusukan juga disebabkan oleh bakteri seperti Pseudomonas, Achromobacter, Flavobacterium maupun Clostridium yang memiliki sifat patogen (Moeljanto, 1994).

Berbagai macam cara pengolahan telah dilakukan untuk menanggulangi kebusukan yang mudah terjadi pada ikan. Salah satu metode pengolahan ikan adalah dengan cara pemindangan. Pindang air garam (pindang cue) merupakan cara pemindangan yang banyak dilakukan pada ikan tongkol. Pindang air garam yang telah diolah kemudian dikemas menggunakan kemasan berupa kranjang atau anyaman bambu, bersifat basah, lunak dan tidak terlalu asin serta tahan disimpan dalam waktu beberapa hari saja (Heruwati, 1985).

Berdasarkan penelitian yang telah dilakukan oleh Purwijantiningsih dan Mursyanti (2006), diketahui mutu bakteriologis pindang tongkol kranjangan yang berasal dari berbagai pasar di Yogyakarta belum sesuai standar SNI. Hal tersebut ditunjukkan dengan jumlah mikrobia total yang cukup tinggi berkisar antara $<2,5 \times 10^{1}->6,5 \times 10^{6} \mathrm{CFU} / \mathrm{g}$, sedangkan dari 20 sampel, hanya 1 sampel yang diduga tidak mengandung Vibrio parahaemolyticus dan 4 sampel yang diduga tidak mengandung Salmonella.

Dari penelitian tersebut dapat diketahui bahwa ikan tongkol pindang berpotensi menjadi sumber makanan yang membahayakan kesehatan. Oleh karena itu perlu dilakukan penelitian untuk mengetahui cara pengolahan yang biasa dilakukan di rumah tangga yang dapat mengurangi jumlah bakteri patogen yang terdapat pada ikan pindang sehingga aman untuk disantap. Penelitian ini bertujuan untuk mengetahui pengaruh cara pengolahan terhadap mutu bakteriologis ikan tongkol pindang, sehingga dapat merekomendasikan cara pengolahan yang dapat dilakukan oleh rumah tangga untuk mendapatkan ikan tongkol pindang siap santap yang aman.

\section{Metode Penelitian}

Bahan yang digunakan adalah ikan tongkol pindang yang berasal dari pasar
Condongcatur di Yogyakarta, medium Plate Count Agar (PCA), Brilliant Green Lactose Bile Broth (BGLB), Baird Parker, medium Chrom agar untuk Salmonella dan Vibrio, larutan pengencer, laktosa cair dan Tetrathionate Broth Base (TBB).

\section{Cara Kerja}

\section{Pengolahan ikan tongkol pindang}

Cara pengolahan ikan tongkol pindang dilakukan berdasarkan kebiasaan di rumah tangga, yakni: ikan pindang goreng, ikan pindang goreng tepung, ikan pindang goreng telur dan ikan pindang goreng pedas dengan pengunaan cabai merah.

\section{Uji bakteriologis}

Uji bakteriologis meliputi total mikrobia, uji Staphylococcus aureus, Coliform, Salmonella dan Vibrio (Fardiaz, 1989; Rahayu, 2003). Uji total mikrobia menggunakan medium Plate Count Agar (PCA), uji bakteri coliform menggunakan medium Brilliant Green Lactose Bile Broth (BGLB). Uji Salmonella menggunakan medium selektif Chrom agar, sebelumnya sampel diresusitasi dengan laktosa cair dan dilakukan pengkayaan dengan Tetrathionat Broth Base (TBB), selanjutnya dilakukan uji pendugaan pada medium Triple Sugar Iron (TSI) dan Lysine Indole Motility (LIM). Uji Vibrio menggunakan medium selektif Chrom agar, sebelumnya sampel diperkaya dengan Alkaline Peptone Water (APW).

Uji bakteriologis dilakukan terhadap ikan tongkol pindang yang sudah mengalami pengolahan dan tidak diolah sebagai kontrol. Pengujian dilakukan setelah 12 jam pengolahan dengan pertimbangan waktu tersebut merupakan jarak antara pemasakan dengan waktu makan malam.

\section{Hasil dan Pembahahasan}

\section{Total mikrobia pada ikan tongkol pindang hasil olahan}

Berdasarkan hasil penelitian diketahui bahwa proses pengolahan dapat mengurangi jumlah total mikrobia yang terdapat pada ikan 
tongkol pindang (Tabel 1). Jumlah total mikrobia pada ikan tongkol pindang yang digoreng pedas berjumlah $3,9 \times 10^{3} \mathrm{CFU} / \mathrm{g}$, sedangkan jumlah mikrobia pada ikan tongkol pindang yang digoreng tepung, goreng telur dan hanya digoreng berturut-turut sebesar 2,08 x $10^{4}, 1,99 \times 10^{4}$ dan $4,47 \times 10^{4}$ CFU/g. Jumlah tersebut lebih sedikit dibandingkan jumlah total mikrobia pada ikan tongkol pindang tanpa pengolahan (kontrol) sebesar $3,58 \times 10^{6} \mathrm{CFU} / \mathrm{g}$.

Pengolahan dalam hal ini pemanasan dapat menurunkan jumlah mikrobia sebanyak 2-3 log $\left(10^{2}-10^{3}\right)$. Penurunan tertinggi didapatkan pada ikan tongkol pindang yang digoreng pedas, yaitu penggorengan dengan pemberian cabai merah (Gambar 1). Hal tersebut disebabkan pada cabai ditemukan senyawa yang berperan sebagai antimikrobia.

Menurut Naim (2004), suatu kandungan terpenoid pada cabai yang dikenal dengan nama capsaicin bersifat bakterisidal terhadap
Helicobacter pylori. Terpenoid yang disebut petalostemumol memperlihatkan aktivitas terhadap Bacillus subtilis, Staphylococcus aureus, bakteri Gram negatif dan Candida albicans.

Berdasarkan penelitian dapat diketahui bahwa tidak semua bakteri mati karena proses penggorengan. Menurut Fardiaz (1992), semakin tinggi jumlah sel mikrobia semakin tinggi tingkat ketahanannya terhadap panas. Diduga bahwa mekanisme perlindungan sel terhadap panas di dalam suatu populasi sel yang tinggi disebabkan sel memproduksi komponen-komponen pelindung, diantaranya protein yang diketahui mempunyai sifat sebagai pelindung. Kemungkinan lain dari peningkatan ketahanan panas dengan meningkatnya populasi sel adalah karena peluang untuk mendapatkan sel yang mempunyai ketahanan panas tinggi semakin besar dengan semakin banyaknya jumlah sel.

Tabel 1. Total mikrobia (CFU/g) pada ikan tongkol pindang hasil olahan

\begin{tabular}{lc}
\hline \hline Cara Pengolahan & Jumlah Total Mikrobia (CFU/g) \\
\hline \hline Tanpa diolah & $3,58 \times 10^{6 \mathrm{a}}$ \\
Goreng & $4,47 \times 10^{4 \mathrm{~b}}$ \\
Goreng tepung & $2,08 \times 10^{4 \mathrm{~b}}$ \\
Goreng telur & $1,99 \times 10^{4 \mathrm{~b}}$ \\
Goreng pedas & $3,90 \times 10^{3 \mathrm{c}}$ \\
\hline \hline
\end{tabular}

Keterangan: Angka yang diikuti huruf yang sama tidak beda nyata pada taraf kepercayaan 95\%

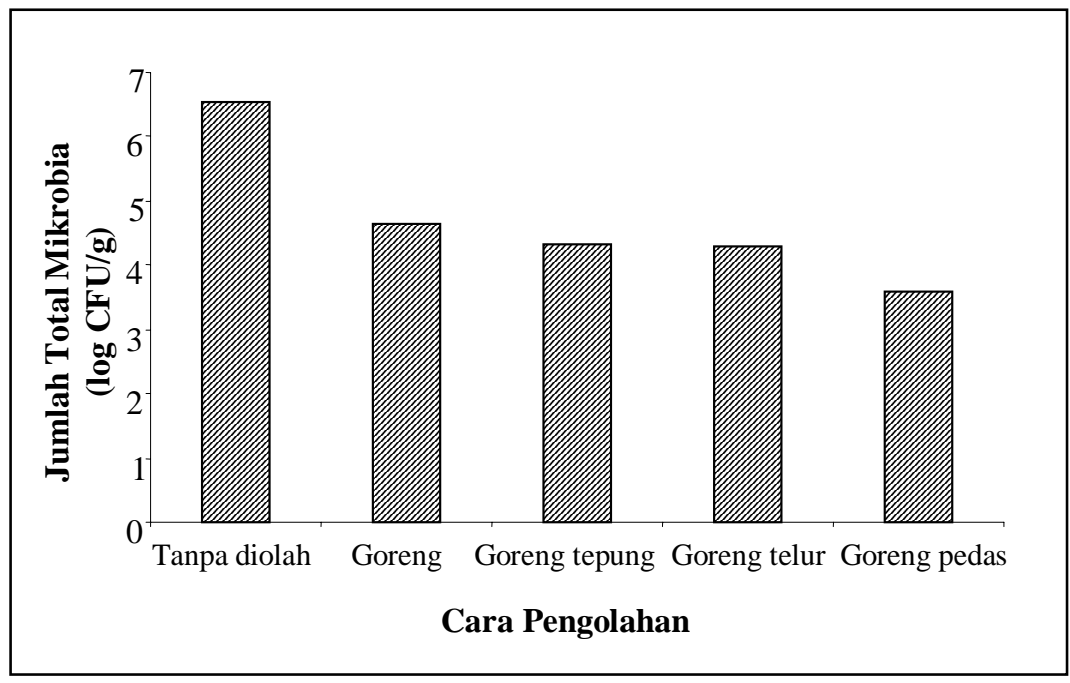

Gambar 1. Total mikrobia (log CFU/g) pada ikan tongkol pindang hasil olahan 


\section{Keberadaan Staphylococcus aureus pada ikan tongkol pindang hasil olahan}

Berdasarkan hasil penelitian ini juga diketahui bahwa pengolahan dengan penggorengan pedas dapat menurunkan jumlah bakteri S. aureus terbanyak dibandingkan pengolahan lainnya (Tabel 2 dan Gambar 2). Pada ikan tongkol pindang tanpa diolah terdapat $S$. aureus sebanyak 4,58 × $10^{5} \mathrm{CFU} / \mathrm{g}$, sedangkan jumlah $S$. aureus pindang ikan tongkol yang digoreng tepung, goreng telur, goreng dan goreng pedas berturut-turut 4,22 $\mathrm{x}$ $10^{3}, 3,23 \times 10^{3}, 2,66 \times 10^{3}$ dan $2,21 \times 10^{2}$ CFU/g. Bakteri S. aureus yang terdapat pada ikan tongkol pindang yang digoreng pedas turun sebanyak $3 \log \left(10^{3}\right)$, sedangkan pengolahan lainnya menyebabkan bakteri tersebut turun sebanyak $2 \log \left(10^{2}\right)$.
Jumlah bakteri $S$. aureus yang terdapat pada ikan tongkol pindang yang digoreng tepung maupun goreng telur lebih banyak jumlahnya dibanding yang digoreng saja. Hal tersebut disebabkan proses penggorengan dengan tepung dan penggorengan dengan telur lebih banyak melibatkan kontak dengan tangan orang yang memasak dibandingkan hanya digoreng saja.

Menurut Nuraida (2000), mikrobia dapat mengkontaminasi makanan melalui pekerja atau kontaminasi silang melalui tangan, permukaan dan peralatan yang tidak mengalami proses pembersihan dan sanitasi yang memadai antara satu proses dengan proses lainnya. Pekerja merupakan sumber yang potensial untuk kontaminasi S. aureus. Mikrobia ini sering ditemui pada hidung dan kulit serta mudah berpindah dari pekerja ke makanan.

Tabel 2. Keberadaan Staphylococcus aureus (CFU/g) pada ikan tongkol pindang hasil olahan

\begin{tabular}{lc}
\hline \hline Cara Pengolahan & Jumlah Staphylococcus aureus (CFU/g) \\
\hline \hline Tanpa diolah & $4,58 \times 10^{5 \mathrm{a}}$ \\
Goreng & $2,66 \times 10^{3 \mathrm{~b}}$ \\
Goreng tepung & $4,22 \times 10^{3 \mathrm{~b}}$ \\
Goreng telur & $3,23 \times 10^{3 \mathrm{~b}}$ \\
Goreng pedas & $2,21 \times 10^{2 \mathrm{C}}$ \\
\hline \hline
\end{tabular}

Keterangan: Angka yang diikuti huruf yang sama tidak beda nyata pada taraf kepercayaan 95\%

Tabel 3. Jumlah Coliform (MPN/g) pada ikan tongkol pindang hasil olahan

\begin{tabular}{lc}
\hline Cara Pengolahan & Jumlah Coliform (MPN/g) \\
\hline \hline Tanpa diolah & $240^{\mathrm{a}}$ \\
Goreng & $15^{\mathrm{b}}$ \\
Goreng tepung & $29^{\mathrm{b}}$ \\
Goreng telur & $16^{\mathrm{b}}$ \\
Goreng pedas & $4^{\mathrm{c}}$ \\
\hline \hline
\end{tabular}

Keterangan: Angka yang diikuti huruf yang sama tidak beda nyata pada taraf kepercayaan 95\%

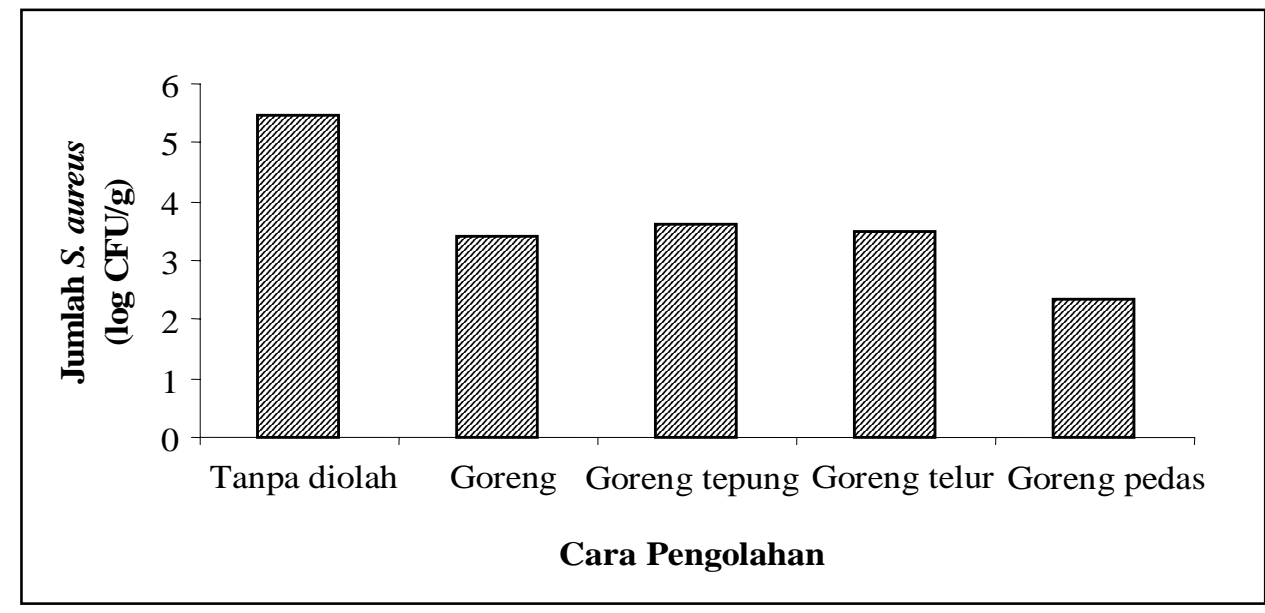

Gambar 2. Jumlah Staphylococcus aureus (log CFU/g) pada ikan tongkol pindang hasil olahan 


\section{Keberadaan bakteri Coliform pada ikan tongkol pindang hasil olahan}

Jumlah Coliform yang terdapat pada ikan tongkol pindang berkurang dengan adanya proses pengolahan (Tabel 3 dan Gambar 3). Pada ikan tongkol pindang tanpa diolah dijumpai bakteri Coliform sebanyak 240 MPN/g, setelah digoreng tepung, goreng telur, goreng biasa dan goreng pedas, jumlah Coliform menjadi berkurang berturut-turut sebesar 29, 16, 15 dan 4 MPN/g. Sama seperti pada jumlah total mikrobia dan $S$. aureus, perlakuan penggorengan pedas dengan penambahan cabai menyebabkan jumlah bakteri Coliform berkurang paling banyak dibandingkan pengolahan lainnya.

Adanya mikrobia Coliform dalam makanan olahan menunjukkan praktek pengolahan yang buruk seperti bahan mentah yang terkontaminasi atau pengolahan yang tidak cukup, kontaminasi personalia, pembersihan dan sanitasi peralatan yang tidak tepat. Pada proses pemindangan yang tidak menggunakan air yang bersih dapat menyebabkan ikan tongkol pindang mengandung Coliform yang cukup tinggi. Hal tersebut dapat disebabkan air bersih sulit didapatkan di lokasi pengolahan ikan. Menurut Sikorski et al., (1998), Enterobacteriaceae sering ditemukan pada ikan olahan yang berkadar air tinggi juga Salmonella typhimurium dan Vibrio parahaemolyticus.

\section{Keberadaan Salmonella pada ikan tongkol pindang hasil olahan}

Pada ikan tongkol pindang tanpa diolah dijumpai adanya bakteri yang diduga Salmonella dan V. parahaemolyticus. Adanya bakteri Salmonella mungkin karena ikan pindang dijual berdekatan dengan bahan pangan yang berpotensi mengandung bakteri tersebut seperti pedagang ayam, daging maupun sayur-sayuran (Purwijantiningsih dan Mursyanti, 2006).

Pada pindang yang telah diolah dengan cara digoreng, goreng tepung, goreng telur dan goreng pedas tidak dijumpai adanya bakteri Salmonella (Tabel 4). Dari hasil tersebut dapat diketahui bahwa proses pemanasan dapat mematikan bakteri Salmonella. Hal tersebut sesuai dengan pendapat Jay (2000) yang menyatakan bahwa bakteri Salmonella adalah bakteri yang tidak tahan panas.

\section{Keberadaan Vibrio parahaemolyticus pada ikan tongkol pindang hasil olahan}

Ditemukannya bakteri yang diduga $V$. parahaemolyticus pada ikan tongkol pindang tanpa diolah dapat disebabkan proses pemindangan belum mematikan semua $V$. parahaemolyticus yang ada atau dapat juga disebabkan karena kontaminasi silang, misalnya wadah yang digunakan, kontaminasi dari proses transport atau lingkungan di sekeliling tempat pindang tersebut disimpan (Purwijantiningsih dan Mursyanti, 2006).

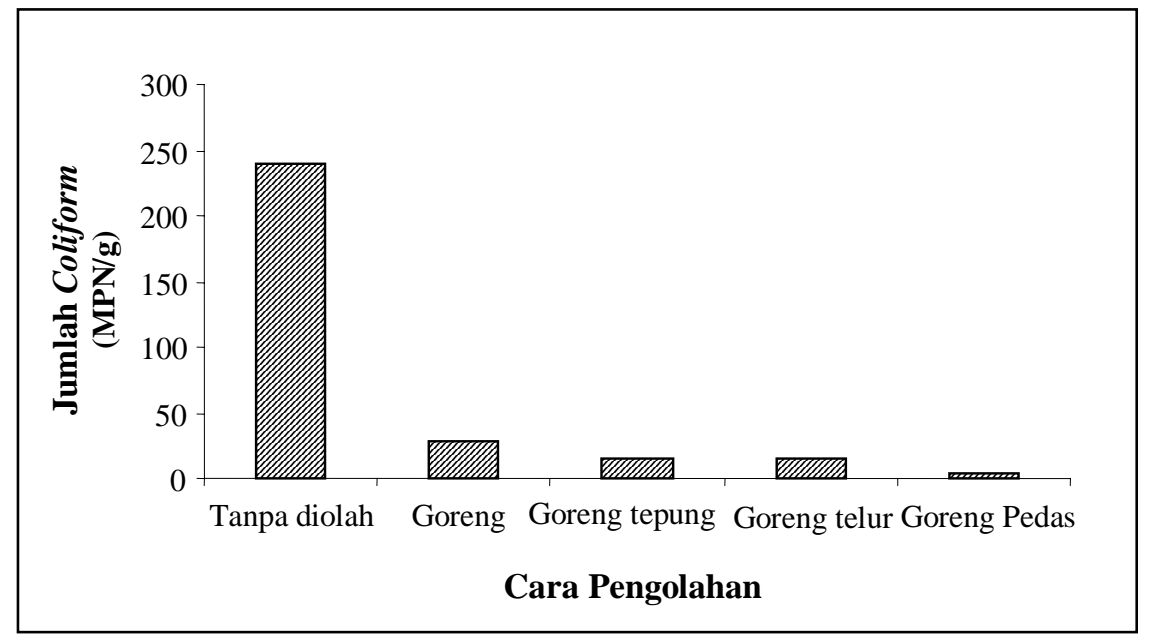

Gambar 3. Hasil uji Coliform (MPN/g) pada ikan tongkol pindang hasil olahan 
Tabel 4. Keberadaan Salmonella pada ikan tongkol pindang hasil olahan

\begin{tabular}{lc}
\hline \hline Cara Pengolahan & Keberadaan Salmonella \\
\hline \hline Tanpa diolah & + \\
Goreng & - \\
Goreng tepung & - \\
Goreng telur & - \\
Goreng pedas & - \\
\hline \hline
\end{tabular}

Keterangan: + = terdapat Salmonella, - = tidak dijumpai Salmonella

Tabel 5. Keberadaan Vibrio parahaemolyticus pada ikan tongkol tongkol hasil olahan

\begin{tabular}{lc}
\hline \hline Cara Pengolahan & Keberadaan Vibrio parahaemolyticus \\
\hline \hline Tanpa diolah & + \\
Goreng & - \\
Goreng tepung & - \\
Goreng telur & - \\
Goreng pedas & - \\
\hline \hline
\end{tabular}

Keterangan: + = terdapat $V$. parahaemolyticus, - = tidak dijumpai $V$. parahaemolyticus

Vibrio parahaemolyticus merupakan bakteri yang umum terdapat pada ikan dan makanan laut lainnya. Menurut Nuraida (2000), bakteri tersebut dapat dihilangkan dengan pemanasan, akan tetapi sanitasi yang kurang baik akan menyebabkan terjadinya rekontaminasi. Hal ini sesuai dengan hasil penelitian yang menunjukkan ikan tongkol pindang yang telah digoreng, goreng tepung, goreng telur dan goreng pedas tidak dijumpai adanya $V$. parahaemolyticus (Tabel 5).

\section{Kesimpulan}

Pengolahan dengan berbagai cara penggorengan dapat menurunkan jumlah total mikrobia, Staphylococcus aureus dan Coliform yang terdapat pada ikan tongkol pindang. Penggorengan pedas dengan menggunakan cabai merah merupakan metode yang dapat menurunkan jumlah mikrobia terbanyak baik total mikrobia, Staphylococcus aureus dan Coliform. Pada ikan tongkol pindang yang telah digoreng tidak dijumpai bakteri yang diduga Salmonella ataupun Vibrio parahaemolyticus.

\section{Ucapan Terima Kasih}

Para peneliti mengucapkan terima kasih kepada Febrianto dan Antonius Indra Sakti yang telah membantu proses penelitian ini.

\section{Daftar Pustaka}

Fardiaz, S. 1989. Analisis Mikrobiologi Pangan. PAU Pangan dan Gizi Institut Pertanian Bogor.

Fardiaz, S. 1992. Mikrobiologi Pangan I. PAU Pangan dan Gizi Institut Pertanian Bogor, Bogor.

Heruwati, E.S. 1985. Prospek dan masalah yang dihadapi dalam pengembangan ikan pindang di Indonesia. J.Litbang PertanianIV(4):103-107.

Heruwati, E.S. 2002. Pengolahan ikan secara tradisional: Prospek dan peluang pengembangan. $J$. Litbang Pertanian XXI (3): 92-99.

Jay, J.M. 2000. Modern Food Microbiology $6^{\text {rd }}$ ed. Chapman \& Hall, New York.

Moeljanto. 1994. Pengawetan dan Pengolahan Hasil Pertanian. Penebar Swadaya, Jakarta.

Naim, R. 2004. Senyawa antimikroba dari tanaman. KOMPAS. 09/15/2004.

Nuraida, L. 2000. Mikroba pathogen pada makanan dan sumber pencemarnya. In: Hardinsyah \& Rimbawan (Eds.). Analisis Bahaya dan Pencegahan Keracunan Pangan. IPB, Bogor.

Priyono, P.R. dan Rahardjo, S. 2003. Tingkat pengetahuan, sikap dan praktek keamanan pangan pedagang dan kebiasaan pembeli ikan pindang keranjang di kota Yogyakarta. Agrosains 16 (3): 307-324.

Purwijantiningsih, E. dan Mursyanti, E. 2006. Mutu bakteriologis pindang tongkol kranjangan (Euthynnus affinis) yang berasal dari beberapa pasar di Yogyakarta. Biota XI (1): 47-51.

Rahayu, E.S. 2003. Uji Mikrobiologi Bahan Pangan. Fakultas Teknologi Pertanian Universitas Gajah Mada, Yogyakarta.

Sikorski, Z., Haard, N., Motohiro, T. and Pan, B.S. 1998. Quality. In: Burt, J.R. Fish Smoking and Drying, the Effect on the Nutrion Properties of Fish. Elsevier Applied Science. London. 